\title{
Liberalism and Capabilities: Theories of Justice and the Neutral State
}

\author{
Percy B. Lehning ${ }^{1}$
}

\begin{abstract}
Modern liberal theories share the idea that the state and its laws should remain neutral with respect to the varying conceptions of the good life held by individuals. This article discusses the way in which this notion of neutrality is defined and justified. Rawls's theory of justice is shown to be a prime example of such a theory. Questions are raised, however, if Rawls's theory has adequately formulated the conditions that would make it possible for each citizen to fulfill his own conception of the good. After arguing that Dworkin's solution to this problem is also problematic, it is argued that Sen's solution to the question of what conditions create neutrality shows the way ahead.
\end{abstract}

KEY WORDS: liberalism; justice; neutrality; capabilities; the liberal state.

\section{INTRODUCTION}

Discussions of what is required for a liberal political order have recently acquired a new impetus. Questions as to what the main features of a constitutional regime should be or, more generally, what the role of the state should be are hotly discussed. In this article the answers given by modern liberal theorists are discussed.

Modern liberal theories typically begin with an analysis of one claim: In a liberal political order, political principles are to be neutral. Stated more precisely, it is the principle that the state and its laws should remain neutral with respect to the varying conceptions of the good life held by individuals. This principle of neutrality is recognized to be an important aspect of liberalism because it enables individuals to have the freedom to

${ }^{1}$ Department of Public Administration, Erasmus University, Postbox 1738, 3000 DR Rotterdam, The Netherlands. 
choose between alternative conceptions of the good life. The importance of this principle in liberal theory is recognized by many different theorists such as Ackerman (1980), Alexander and Schwarzschild (1987), Barry (1990a, 1990b) Dworkin (1978, 1983), Galston (1982), Larmore (1987), Rawls $(1971,1987,1988,1989)$, Raz (1986), and Sandel (1982). Some theorists, for instance, Larmore and Rawls, are staunch defenders of the principle of neutrality. ${ }^{2}$ Others, for example, Galston, Raz, Sandel, and Alexander and Schwarzschild, reject the principle for a variety of reasons.

The structure of this article is as follows: First the question is discussed of how the liberal notion of neutrality of the state is to be defined and why it should be defended at all. In this context, a relation between the ideas of a neutral state and freedom of choice is demonstrated. An example of a theory that specifies and defends a doctrine of political neutrality is presented: Rawls's political conception of justice. Criticisms advanced against the liberal principle of neutrality are dealt with. These kinds of criticism are illustrated by Raz's critique and Sandel's communitarian critique.

Then, the question is raised as to how the state could create conditions that make it possible for citizens to have the opportunity to choose between different conceptions of the good. The solutions presented by Rawls and Dworkin raise many problems. It is argued that Sen's alternative answer to this question is more satisfactory. The conclusion of this article is that a liberal political order can exist only if it is based on the principle of neutrality of the state.

\section{POLITICAL NEUTRALITY AND FREEDOM}

The central argument favoring the liberal notion of neutrality is that it is necessary if one acknowledges that there exist a variety of conceptions of the good life. There are many ways in which a fulfilled life can be lived, without any perceptible hierarchy among them. As Larmore has formulated it in his defense of neutrality in modern liberal societies, pluralism and reasonable disagreement have become for modern thought ineliminable features of the idea of the good life (Larmore, 1987, p. 23). (See Appendix A.)

In response to pluralism and reasonable disagreement, political liberalism formulates the principle that the state should be neutral.

${ }^{2}$ Larmore's Patterns of Moral Complexity (1987) gives the most elaborate defense of political neutrality presently available. The article, especially the general ideas on neutrality, owes a lot to the ideas formulated in that book. 
The state should not seek to promote any particular conception of the good life because of its presumed intrinsic superiority-that is, because it is supposedly a truer conception. (Larmore, 1987, p. 43)

And Raz (1986), who interprets this neutral political concern as an antiperfectionist principle, suggests that this principle

claims that implementation and promotion of ideals of the good life, though worthy in themselves, are not a legitimate matter for governmental action. The doctrine of political neutrality seeks to implement it through a policy of neutrality. Government action should be neutral regarding ideals of the good life. (p. 110)

Neutrality is seen as a political ideal, it governs a state's policies and institutions, the public relations between persons and the state, and not the private relations between persons and other institutions. Liberalism is in this view not seen as a philosophy of man, but as a philosophy of politics (Larmore, 1987, p. 129). (As shown in the next section, Rawls, 1985, 1987, 1988, 1989, defends the same position.)

Now the liberal idea of neutral political order can be understood in two different ways, as De Marneffe has argued. The first idea can be called constitutional neutrality: "a system of laws is neutral if, as a whole, it can be justified solely in terms of neutral values" (1989, pp. 52-53; 1990, p. 259). The second idea is legislative neutrality: "a system of laws is neutral when there is no law which cannot itself be justified in terms of neutral values (or: for every law, there is a neutral reason which warrants it) (1989, p. 53; 1990 , p. 259). In this article we are concerned with constitutional neutrality: Each citizen has sufficient reason to accept the basic social and political institutions of his society because those institutions are neutral between conceptions of the good, in the sense that they are acceptable to reasonable citizens who hold different particular conceptions of the good.

An implication of political neutrality, in this sense, is that there is a constraint on the factors that can be invoked to justify political values. Constitutional decision making can count as neutral only if it can be justified without appealing to the presumed intrinsic superiority of any particular conception of the good life (Larmore, 1987, p. 44). The justification of constitutional neutrality is based on the wish to show everyone equal concern and respect. Other persons are due equal respect by virtue of their capacity to work out their own conception of the good life (Larmore, 1987, pp. 59-66; Dworkin, 1977, pp. 180, 272; 1978, p. 127; Raz, 1986, p. 220).

The stress upon neutrality and equal respect, which denies the state any right to implement any specific conception of the good life, emphasizes the equal freedom that all persons should have to pursue their own conception of the good life. As Raz (1986), for instance, formulated it: "The conflict in which the state is supposed to be neutral is about the ability of people to choose and successfully pursue conceptions of the good" (p. 123). 
With this conception of neutrality, the state can be neutral only, according to Raz "if it creates conditions of equal opportunities for people to choose any conception of the good, with an equal prospect of realizing it" (p. 124). So equal freedom of choice and political neutrality necessarily go hand in hand, according to this argument. Now Raz's formulation of "neutrality" as the equal prospect of realizing one's conception of the good is a rather strong one. I do not want to elaborate on this point here but simply assume that we are talking about a reasonable opportunity for each citizen to realize his conception of the good. Or, following Rawls's (1988, p. 262) formulation of neutrality as an aim of the state, we understand it to mean that the state ensures for all citizens equal opportunity to advance any permissible conception of the good, namely, those conceptions that respect the principle of "justice as fairness."

To be more precise, in this article we opt for a "comprehensive principle of neutrality," defined by Raz (1986) in the following way:

One of the main goals of governmental authority, which is lexical prior to any other, is to ensure for all persons an equal ability to pursue in their lives and promote in their societies any ideal of the good of their choosing. (p. 115)

(Raz (1986) himself rejects not only this principle of neutrality but all principles of neutrality, in line with his defense of perfectionism. See section "The Liberal Critique of Neutrality: Raz.") In what follows, political neutrality is understood in this way.

Recapitulating: We have seen that liberalism is defined as a theory in which one of the main values of the political order-political justice-is defined by the neutrality of the state. The fundamental political principles, by which all individuals are to live, must be justified without appeal to the intrinsic superiority of any conception of the good. Such principles assign to persons rights and duties and define the appropriate distribution of the benefits and burdens of social cooperation. These principles are the principles of social justice. They are liberal principles because they take a neutral stand with regard to different conceptions of the good (Rawls, 1971, p. 4).

Rawls's theory of justice is the prime example of a theory that develops such principles. It is to this theory that we now turn.

\section{POLITICAL NEUTRALITY AND RAWLS'S THEORY OF JUSTICE}

Without any doubt the richest and most serious attempt to specify and defend a doctrine of political neutrality is the one formulated by Rawls. 
In particular his articles published since his Dewey Lectures make his position in the "neutrality debate" very clear (Rawls, 1982, 1985, 1987, 1988, 1989). I concentrate on recent publications of Rawls, such as "The Idea of an Overlapping Consensus" (1987) and "The Priority of Right and Ideas of the Good" (1988). One could argue that while $A$ Theory of Justice (1971) was harboring, side by side, a Kantian approach and a political conception of justice, in Rawls's more recent articles (especially the one's published in 1985, 1987, 1988, and 1989), Justice as faimess is distinctly seen as a political conception of justice that reflects the "working out" (not the "application") of a moral conception. In other words, since 1985, Rawls has clarified the political dimensions of justice as fairness to emphasize the political, as opposed to the metaphysical, foundations of his theory. (See also Wallach, 1987, pp. 582-583, on the development in Rawls's theory, as can be deduced from Rawls, 1982, 1985, 1987.) The moral subject of his theory is now quite clearly the citizen. Before we elaborate on Rawls's recent views however, a few preliminary remarks are made that will be of use in the following argument.

Larmore has distinguished two different views of the relation between the political order and ideals of the person. The first is the modus vivendi perspective, the second the expressivist one (Larmore, 1987, pp. 74, 91). The first view is the one in which the political order is seen as predominantly a modus vivendi, a means of accommodation among individuals having divergent conceptions of the good life. Political neutrality is in this case the primary political ideal, although it implies no repudiation or lessening of attachment to substantive conceptions of the good life one may have outside the political realm, in one's personal ideals.

The second view (Larmore, 1987), opposed to the first one, is expressivism: "It requires that the political order express our personal ideal, in the sense that its highest ideal must mirror or coincide with what are in general our deepest commitments" (p. 91). In recent articles, Rawls clearly rejects this expressivist view. At the same time he makes clear in his elaboration of his political conception of justice that his interpretation of liberalism differentiates between personal and political ideals, between homme and citoyen. His theory should be interpreted as a theory about citoyen.

In "The Idea of an Overlapping Consensus" Rawls (1987) articulates three features of a political conception of justice. The first constitutes the substantive principles of justice, worked out to apply to the basic structure of a modern constitutional democracy. The second feature complements the first and is the most important in respect of our present discussion.

[A] political conception is not to be understood as a general and comprehensive moral conception that applies to the political order, as if this order was only another 
subject, another kind of case, falling under that conception. Thus, a political conception of justice is different from many familiar moral doctrines, for these are widely understood as general and comprehensive views. Perfectionism and utilitarianism are clear examples, since the principles of perfection and utility are thought to apply to all kinds of subjects ranging from the conduct of individuals and personal relations to the organization of society as a whole, and even to the law of nations. . . . By contrast, a political conception of justice involves, so far as possible, no prior commitment to any wider doctrine. It looks initially to the basic structure and tries to elaborate a reasonable conception for that structure alone. (pp. 3-4)

One reason for this focus on a political conception for the basic structure is that, as a practical matter, no general and comprehensive view can provide a publicly acceptable basis for a political conception of justice. So, the political conception of justice must allow for a diversity of general and comprehensive doctrines, and for the plurality of conflicting and indeed incommensurable conceptions of the good (Rawls, 1971, p. 94; 1987). This diversity of doctrines, this political fact of pluralism is, according to Rawls, a permanent feature of the public culture of modern society, so that one has to look for a basis of agreement other than that of a general and comprehensive doctrine. The task then becomes to look for a political conception of justice that might be supported by an overlapping consensus. ${ }^{3}$

The importance of the second feature of a political conception of justice should not be underestimated, especially in regard to Rawls's earlier position as formulated in $A$ Theory of Justice. The second feature denies not only that general and comprehensive doctrines might give a basis for a shared view but also for many forms of liberalism.

Although any workable conception of political justice must be "liberal" this will not be, according to Rawls $(1987$, p. 5), the liberalism of Kant or Mill. (See also Nagel, 1987, for a discussion on the aspect of liberalism depending on the acceptance of a higher order impartiality and the problems such a defense raises.) The public role of a neutrally recognized political conception of justice is to specify a point of view from which all citizens can examine before one another whether or not their political institutions are just.

\footnotetext{
${ }^{3}$ It should be made clear that Rawls makes a distinction between an overlapping consensus and a modus vivendi. An overlapping consensus is not the same as a modus vivendi because the first is connected with stability. An overlapping consensus is independent of shifts in the distribution of power, while in Rawls's view the stability of a modus vivendi depends on happenstance and a balance of relative forces $(1987$, p. 11). As we have seen earlier Larmore makes a distinction between a modus vivendi view and the expressivist one. In Larmore's modus vivendi view there is (partial) agreement on grounds that neither implies nor automatically produces an agreement on political principles. In Rawls's idea of an overlapping consensus there is normative agreement on political principles but not on the grounds that justify them. (See Richardson, 1990, pp. 9-11, for a helpful clarification of the different configurations that are the result of the facts of pluralism.) In this article, I understand the term "modus vivendi" to have the same meaning as the term "overlapping consensus."
} 
It enables them to do this by citing what are recognized among them as valid and sufficient reasons singled out by that conception itself. Questions of political justice can be discussed on the same basis by all citizens, whatever their social position, or more particular aims and interests, or their religious, philosophical or moral views. ... Given the fact of pluralism, and given that justification begins from some consensus, no general and comprehensive doctrine can assume the role of a publicly acceptable basis of political justice. (Rawls, 1987, p. 6)

This conclusion makes it clear what are the problematic aspects of the liberalism of Kant and Mill. Both are general and comprehensive moral doctrines, they comprehend far more than the political.

Their doctrines of free institutions rest in large part on ideals and values that are not generally, or perhaps even widely, shared in a democratic society. They are not a practicable public basis of a political conception of justice. (Rawls, 1987, p. 6) ${ }^{4}$

This leads to the third feature of a political conception of justice, namely, that the political conception is not formulated in terms of a general and comprehensive religious, philosophical, or moral doctrine but rather "in terms of certain fundamental intuitive ideas viewed as latent in the public political culture of a democratic society" (Rawls, 1987, p. 6).

Now, of course, the political conception of justice Rawls has in mind is his own conception: "justice as faimess." Another example of a political conception of justice is Dworkin's (1978, 1981a, 1981b, 1983) liberal conception of equality.

Justice as fairness is intended to solve the fundamental question of political justice, namely, what is the most appropriate conception of justice for specifying the terms of social cooperation between citizens regarded as free and equal persons (Rawls, 1985, p. 234; 1987, p. 7).

Citizens are free in that they conceive of themselves and others as having a conception of the good, independent of any particular conception of the good, or scheme of final ends. They are also free in that they view themselves as self-originating sources of valid claims. Third, they are free in the sense that they are capable of taking responsibility for their ends and this affects how their various claims are assessed (Rawls, 1985, pp. 239-244).

Thus, to recapitulate, we have seen that liberalism is understood by Rawls to be a political doctrine, which supposes that there are many conflicting conceptions of the good. Such a diversity of conceptions makes it necessary to search for a political conception of justice that will regulate the terms of social cooperation between citizens in such a way that each person will have the equal ability to pursue in the "nonpublic" sphere the ideal of the good of his own choosing.

${ }^{4}$ See also Rawls (1985, pp. 245-248; 1988, pp. 267-268). 
One can conclude that Rawls's recent articles formulate and defend an unequivocal plea for the comprehensive principle of neutrality with the intention of guaranteeing each person the equal freedom of choice of his conception of the good. (See also Rawls, 1988, p. 262. He there draws on Raz's formulation of three versions of neutrality. Justice as fairness satisfies, according to Rawls the "comprehensive principle of neutrality".)

\title{
POLITICAL NEUTRALITY AND SOME CRITICS
}

\section{The Communitarian Critique of Neutrality: Sandel}

The core of the communitarian critique against the liberal principle of neutrality rejects the idea that the political order should remain neutral toward different ideals of happiness and self-realization, toward different conceptions of the good. ${ }^{5}$ Larmore (1987) has summarized this communitarian position in the following way:

\begin{abstract}
Because no one can determine with full autonomy how he shall see the world and what goals he shall pursue, but instead can come to understand himself only through participating in shared traditions and social forms-because in some areas he should not even strive for autonomy, the primary role of the state must be not to sustain a kind of neutrality, but rather to embody and foster some particular conception of the good life. (p. 92)
\end{abstract}

In communitarianism the relation between the political order and ideals of the person is understood in terms of what has earlier been described as expressivism. It demands, in general, that our personal ideal should be mirrored in our highest political ideal, that is, the political ideal should mirror our ideal of what should have paramount importance in our lives. In the communitarian view, expressivism is connected with the nonliberal view that the state must foster some substantial ideal of the good life in its citizens. Community should fulfill a common purpose.

A typical example of this line of reasoning is to be found in Sandel's Liberalism and the Limits of Justice (1982). ${ }^{6}$ According to Sandel, the main problem with liberalism is that its foundations are faulty: To achieve ab-

${ }^{5}$ For an overview and a discussion of the recent communitarian literature see: Wallach (1987); Gutmann (1985); Taylor (1989); Thigpen and Downing (1987). See also for a critique of recent objections and misinterpretations formulated by communitarians like Sandel, MacIntyre, and Rorty against the antiperfectionism of liberals like Rawls and Dworkin: Kymlicka (1988). In this article I discuss only what is called "teleological communitarianism" as formulated by, for instance, Sandel and MacIntyre. I do not elaborate on nonteleological communitarian ideas, as formulated by, for instance, Rorty (1988).

${ }^{6}$ For discussion and critique of Sandel (1982): see Larmore (1987, pp. 121-129); Gutmann (1985, pp. 310-314); Wallach (1987, pp. 591-596); Taylor (1989). 
solute priority for principles of justice, liberals must hold a set of implausible metaphysical views about the self. They cannot admit, Sandel remarks that, for example, our personal identities are partly defined by our communal attachments.

Sandel places Rawls's theory of justice at the center of his critique. He charges Rawls with failing to appreciate the constitutive character of the self because the moral subject of justice as fairness may not be identified by his or her constitutive attachments. The distinction that we noted earlier in Rawls between public and private realms is consequently attacked by Sandel, who correctly understands that Rawls's political theory belongs to the great liberal tradition. It locates the primary ideal of the political order in the neutrality of the state and so in an "abstract" conception of justice. The distribution of political and economic benefits is to be regulated by principles that do not presuppose, for their justification, any particular conception of the good life. In this sense the right is prior to the good. Sandel's critique of Rawls's theory centers around the Kantian form of justification that, he argues, dominates Rawls's work. This Kantian base can justify the primacy of abstract justice only by appealing to an ideal of the person as disencumbered of natural and social circumstances and so prior to its ends and values. For Sandel this ideal of an "disencumberedself" is totally unacceptable.

Sandel's starting point is an expressivist model of the political order. The only condition under which an ideal of what we should be as persons can be connected with a conception of the political order is when this idea is expressed in the primary ideals of that order. Once we recognize that our personhood must be constituted in part by a commitment to some conception of the good life, Sandel (1982, pp. 179-183) argues, we will grasp that the political order too, must subordinate justice to that higher, more substantive ideal. Thus, Sandel forces us to choose in favor of one sort of expressivism, some form of communitarianism.

However, nowhere does Sandel consider the alternative that Larmore called the modus vivendi view, a view that Rawls has elaborated on in his articles published since the Dewey Lectures. In these articles there is, as mentioned earlier, a sharp distinction between how we understand ourselves as citizens within the political system and how we may regard ourselves in our personal affairs or within certain intermediate associations, (See Appendix B.)

Once again, it should be stressed, that the modus vivendi requires only in the political domain to abstract from particular, controversial conceptions of the good life. We should not abstract from our shared interests: for instance, in the way that we value the freedom to choose a good life 
or the freedom at least from having a particular form of life imposed upon us by political authorities.

Rawls himself (1987) has reacted to the objections from the communitarian perspective:

Note that what is impracticable is not all values of community (recall that a community is understood as an association or society whose unity rests on a comprehensive conception of the good) but only political community and its values. Justice as fairness assumes, as other political views do also, that the values of community are not only essential but realizable, first in the various associations that extend across the boundaries of nation-states, such as churches and scientific societies. Liberalism rejects the state as a community because, among other things, it leads to the systematic denial of basic liberties and to the oppressive use of the state's monopoly of (legal) force. (p. 10, note 17$)^{7}$

Liberalism does not, as is clear from the comments by Rawls and Larmore, presuppose metaphysics. As Gutmann (1985) has summarized:

The major aim of liberal justice is to find principles appropriate for a society in which people disagree fundamentally over many questions, including such metaphysical questions as the nature of personal identity. Liberal justice therefore does not provide us with a comprehensive morality; it regulates our social institutions, not our entire lives. It makes claims on us "not because it expresses our deepest self-understanding", but because it represents the fairest possible modus vivendi for a pluralistic society. (p. 313)

The equal ability to pursue in one's life an ideal of the good of one's own choosing, this idea of the freedom of choice, implies the rejection of the idea that the state should or could be seen as a community, defined by a substantive ideal. This idea of freedom of choice does not, one should stress, reject the importance of the idea of "belonging," but it does, indeed, reject Sandel's suggestion that we should give up the "politics of rights" for a "politics of the common good." (See also Larmore, 1987, p. 119, for stressing the importance of "belonging." Sandel's suggestion for a politics of the common good is to be found in Sandel, 1984, p. 17.)

Our conclusion is that the comprehensive principle of neutrality should strongly be defended against the communitarian attacks as formulated by Sandel.

\section{The Liberal Critique of Neutrality: Raz}

As we have seen the doctrine of neutrality between conceptions of the good follows from moral pluralism. In his critique of Rawlsian antiperfectionism, and in the course of his defense of his own version of perfectionism as developed in The Morality of Freedom, Raz (1986) makes

${ }^{7}$ For a direct reaction by Rawls on Sandel: see Rawls (1985, p. 239, note 21). 
the following remark: "Moral pluralism is often thought to necessitate neutral political concern" (p. 133). However, he wants to make clear that there is a logical gap between pluralism and neutrality. No one would, it seems to me, deny this point. The importance of this remark becomes clear when one realizes that $\operatorname{Raz}(1987)$ takes a position in which moral pluralism and neutrality do not, in fact, go together. The disjunction arises because Raz explores:

the rationality of perfectionist moral pluralism, i.e. of pluralism of many forms of the good which are admitted to be so many valuable expressions of people's nature, but pluralism which allows that certain conceptions of the good are worthless and demeaning, and that political action may and should be taken to eradicate or at least curtail them. (p. 133)

Disregarding for the moment the fact that $\operatorname{Raz}$ is evidently not talking about full moral pluralism, but about pluralism to a certain degree ("certain conceptions of the good are worthless and demeaning," those must be "curtailed"), his argument on moral pluralism continues as follows:

Moral pluralism asserts the existence of a multitude of incompatible but morally valuable forms of life. It is coupled with an advocacy of autonomy. It naturally combines with the view that individuals should develop freely to find for themselves the form of the good which they wish to pursue in their life. Both combined lead to political conclusions which are in some way akin to those of Rawls: political action should be concerned with providing individuals with the means by which they can develop, which enables them to choose and attempt to realize their own conception of the good. (p. 133)

One may wonder then what the difference is between the antiperfectionism of Rawls and the perfectionism Raz is defending. ${ }^{8}$ That difference is, according to Raz (1986), that "there is nothing here which speaks for neutrality. For it is the goal of all political action to enable individuals to pursue valid conceptions of the good and to discourage evil or empty ones" (p. 133). So we see that Raz's perfectionism is, in fact, stronger than his interpretation of moral pluralism on first sight seemed to be. Moral pluralism or not, some conceptions of the good are not valid and should be prevented from being realized. Neutrality should not prevail in all situations. This position becomes even more clear when Raz brings in the state. $\mathrm{He}$ "maintains that it is the function of government to promote morality. That means that government should promote the moral quality of life of those whose lives and activities they can affect" (p. 415). And further on:

\footnotetext{
${ }^{8}$ Rawls himself (1988) also notes that there is "some resemblance between the values of political liberalism and the values of the comprehensive liberalisms of Kant and Mill" (p. 268). And in a footnote Rawls adds: "And that of Raz in 'The Morality of Freedom" (p. 268 , note 26 ). The main point is, however, "to set out carefully the great differences in both scope and generality between political and comprehensive liberalism" (p. 268; italics added).
} 
the autonomy principle is a perfectionist principle. Autonomous life is valuable only if it is spent in the pursuit of acceptable and valuable projects and relationships. The autonomy principle permits and even requires governments to create morally valuable opportunities, and to eliminate repugnant ones. (p. 417).

Raz defends this position against the antiperfectionist view in the following way:

The most deeply rooted confusion leading to the intuitive appeal of the anti-perfectionist is the thought that anti-perfectionism is necessary to prevent people from imposing their favored style of life on others. . . This need not be the case. ... If a plurality of incompatible, even rival, forms of life is valuable then perfectionism would not lead to the suppression of forms of life which are not practiced by those in power. (pp. 161-162)

Raz, in other words, argues that pluralism is compatible with perfectionism but incompatible with neutrality. He denies that an endorsement of moral pluralism implies a commitment to political and public neutrality. Moral pluralism is defined by Raz as the view that there are many genuinely conflicting forms of the good life and that none of these competing forms of life have a claim to be publicly entrenched relative to another. This does not, however, imply neutrality because some (perhaps all) of them have a claim to be entrenched in public life relative to some other forms of life. This is because many valuable forms of life require certain public goods, for example, a culture of toleration, which is incompatible with these latter forms of life. And this is why pluralism is compatible with perfectionism but incompatible with neutrality. While defending perfectionism, Raz argues that governments should defend "valid" conceptions of the good and prevent "evil ones." The consequence of the application of this doctrine of Raz might be that it leads to the imposition by the powerful of their way of life. For that reason one should prefer, I think, a doctrine of antiperfectionism, which is based on a concern for the dignity and integrity of individuals and on a revulsion from letting one section of the community impose its favored way of life on the rest. (And this is recognized by Raz himself to be the core of the antiperfectionist position. $)^{9}$

Although, in my view, this would in itself be enough reason to continue to defend "the comprehensive principle of neutrality" against Raz's perfectionism, there is another point that should be made clear in regard to Raz's interpretation of an antiperfectionism like that of Rawls. From

${ }^{9}$ See Raz (1986, p. 162). Nevertheless, Raz (1986) defends and compares his own perfectionism even with communitarian doctrines: "Its perfectionist character, the rejection of moral individualism, and the emphasis placed on the importance of collective goods bring the view here advocated close to various collectivist, or communitarian doctrines" (p. 426). These remarks make it even more clear why Raz's perfectionism should be rejected in the context of our discussion of neutrality. ( 1 am grateful to Albert Weale for clarifying for me Raz's position on pluralism and perfectionism.) 
Raz's rejection of it, one gets the impression that antiperfectionism is seen by him as a vision in which "anything goes." Or, as Raz says: "Anti-perfectionism in practice would lead not merely to a political stand-off from support for valuable conceptions of the good. It would undermine the chances of survival of many cherished aspects of our culture" (p. 162). If the comprehensive principle of neutrality is seen as an antiperfectionist principle, as it is by Raz, then this interpretation of antiperfectionism is much too "strong." As stated earlier, the doctrine that the state should be neutral means that it should not seek to promote any particular conception of the good life because of its presumed intrinsic superiority, that is, because it is supposedly a truer conception (Larmore, 1987, p. 43). However this certainly does not mean, as Raz seems to imply in the statement quoted above, that the state should "stand-off" completely. It may, of course, restrict certain ideals for extrinsic reasons (e.g., those that threaten the lives of others). In that sense one could speak of a "qualified" antiperfectionism.

Political neutrality is, as Larmore (1987) has remarked, a relative matter:

It does not require that the state be neutral with respect to all conceptions of the good life, but only with respect to those actually disputed in the society. Where everyone agrees about some element of human flourishing, the liberal should have no reason to deny it a role in shaping political principles. (p. 67)

We conclude that Raz has failed to demonstrate that one should abandon the comprehensive principle of neutrality, and that the critique of the neutrality principle has, so far, proved unconvincing.

\section{LIBERALISM, NEUTRALITY, AND RESOURCES}

\section{Introductory Remarks}

The neutrality of the state is one of the main values for a liberal political order and we have seen this to mean that the purpose of government activity is to ensure for all persons a reasonable opportunity to pursue the good of their own choosing. The question that now has to be dealt with is how to create conditions of equal opportunity for people to choose any (permissible) conception of the good with a reasonable prospect of realizing that conception.

Alexander and Schwarzschild (1987) have posed the question of what divides liberals if the neutrality principle is the principle that defines and unites them. They argue that there are two questions: 
(1) What resources are up for "neutral" distribution? More specifically do those resources include or exclude persons' bodies, labor, and talents? . . . (2) What is the proper formula for distributing those resources that are up for distribution? (p 86)

They deal in their article with only a part of the second issue. Their focus is on whether there is a neutral way resource holdings can be measured. Their conclusion is "that there is no neutral way of measuring resource holdings, and that such a conclusion seriously undermines liberalism to the extent liberalism rests on an abstract principle of neutrality" (p. 87). At the end of this section we return to their conclusion. First, however, we examine two resourcists' theories of distribution, within the framework of liberal neutrality. Both theories discuss what should be involved in allocating resources in a neutral way and what would have to be done to create conditions of equal opportunity for all citizens to realize their views of the good. The theories that are examined are those of Rawls, with his proposal to equalize, as far as possible, the bundle of primary goods available to each person, and Dworkin, who argues that the ethically relevant equality must be that of equality of resources. Both Rawls and Dworkin have attempted to work out, with the idea of primary goods and that of equality of resources, a neutral theory of resource holdings. In fact, according to Alexander and Schwarzschild, Rawls (and Dworkin) are the only ones of contemporary liberal theorists who have done so.

\section{Rawls's Approach: Primary Goods}

Rawls's (1982) solution to the question of which resources are up for neutral distribution is the concept of primary goods: "social background conditions and all-purpose means generally necessary for forming and rationally pursuing a conception of the good" (p. 169). These goods are "neutral" because they are goods any rational person would want more of rather than less, no matter what that person's view of the good was. The notion of primary goods addresses the moral and practical problem of how, given different and opposing, conceptions of the good, a public understanding still could be possible. It is based on the idea that a partial similarity of citizen's conceptions of the good is sufficient for political and social justice (Rawls, 1982, p. 161).

The primary goods consist of the basic liberties; freedom of movement and choice of occupation; powers and prerogatives of offices and positions of responsibility; income and wealth; and the social bases of selfrespect $(1982$, p. $162 ; 1971$, pp. 60-65). Well-being can be directly accommodated with the index of primary goods, because concentration on bundles of primary goods gives an objective criterion of well-being. 
This list of primary goods has been criticized by several theorist. Nagel (1975), for instance, has criticized Rawls's theory of justice on the ground that it purports to be neutral between different conceptions of the good, but, in fact, is not.

It is a fundamental feature of Rawls conception of the fairness of the original position that it should not permit the choice of principles to depend on a particular conception of the good over which the parties may differ. The construction does not, I think, accomplish this, and there are reasons to believe that it cannot be successfully carried out. Any hypothetical choice situation which requires agreement among the parties will have to impose strong restrictions on the grounds of choice, and these restrictions can be justified only in terms of a conception of the good. It is one of those cases in which there is no neutrality to be had, because neutrality needs as much justification as any other position. (pp. 8-9)

That neutrality needs as much justification as any other position, is certainly correct. ${ }^{10}$ If political liberalism with its conception of the comprehensive principle of neutrality is a response to the variety and contestedness of ideals of the good life, it certainly needs a justification that is itself neutral. However, in the "Political Neutrality and Freedom" section, it has been suggested how such a justification could be given. In the specific case of Rawls it is exactly his construction of "the originai position" that is to be understood as a position of neutrality from which to derive principles of justice. It guarantees the wish to show everyone equal respect, understood as the equal freedom for each person to pursue his conception of the good.

Nagel (1975) however, makes a more valid point when he remarks that "the primary goods are not equally valuable in pursuit of all conceptions of the good" (p. 9). They serve, according to Nagel, some individualist conceptions well enough but "they are less useful in implementing nonindividualist conceptions." (See also Fishkin, 1975 and Schwartz, 1975. For a reaction to Nagel's 1975 critique by Rawls, see Rawls, 1988, p. 264, note 23.)

This is a weaker criticism of the concept of primary goods then that formulated by Sen. As remarked earlier, objective criteria of well-being can be directly accommodated with the index of primary goods. Sen (1988) has stated that the focus on primary goods

has an advantage arising from the fact that a person's actual freedom to lead a life does indeed depend fairly crucially on his or her holding of primary goods, and the index of primary goods can, to that extent, be seen as an index of freedom. (p. 277)

\footnotetext{
${ }^{10}$ See Nagel's (1987) discussion of this problem. Ackerman (1963, p. 387) has argued "that it would be a categorical mistake to imagine that there could be a neutral justification." Larmore (1987) is however, as stated earlier, an attempt to give such a justification. He then, of course, disagrees with Nagel and Ackerman in this regard (Larmore, 1987, p. 161, note 11). See also Barry (1990b) where he argues that the principle of neutrality is not a very attractive principle, not even for liberals.
} 
So, primary goods support freedom of choice. However, there is, as Sen notes, a problem. The advantages that persons possess are judged by reference to the index of primary goods. This means, for instance, that expensive tastes are not a ground for more income. This is justified, according to Rawls, because a person has responsibility for the choice of his own ends. This leads Sen (1982b) to raise the following question:

But what about the cripple with utility disadvantage. . . The Difference Principle will give him neither more nor less on grounds of his being crippled. His utility disadvantage will be irrelevant to the Difference Principle. This may seem hard, and $I$ think it is (p. 365)

One should note here that Rawls justifies the omission of "hard cases" because he wants to postpone the question of how to deal with those cases rather than to ignore it. Problems of special health and medical needs are put, for the time being, aside by him. He assumes that "all citizens have physical and psychological capacities within a certain normal range" (1982b, p. 168). ${ }^{12}$ Sen quite rightly, I think, points out that differences of needs-of which hard cases are just extreme examples-are pervasive and deserve a more central place in a theory of justice such as Rawls' (Sen, 1982b, p. 366 , note $28 ; 1989$, p. 27 , note 41 ). He concludes that leaving those cases out may guarantee that "mistakes" will be made (Sen, 1982a, p. 14; 1984, p. $320 ; 1988$, p. 278). However, the problem does not end with hard cases. Sen (1982b) makes an even more important point:

\begin{abstract}
The primary goods approach seems to take little note of the diversity of human beings. . . . If people were basically very similar, then an index of primary goods mights be quite a good way of judging advantage. But, in fact, people seem to have different needs varying with health, longevity, climatic conditions, location, work conditions, temperament, and even body size (affecting food and clothing requirements). So what is involved is not merely ignoring a few hard cases, but overlooking very widespread and real differences. Judging advantage purely in terms of primary goods leads to a partially blind morality. (p. 366)
\end{abstract}

The interpersonal variations, even when they are exceptional, may call for urgent attention, since they may relate to especially important problems, e.g., the freedom of the disabled people to move about freely and to take part in the life of the community (Sen, 1988, p. 278). There are, Sen concludes: "widespread and ubiquitous variations in our ability to convert primary goods into functionings and well-beings" (p. 278). Although Rawls's

\footnotetext{
${ }^{11}$ Alexander and Schwarzschild (1987) formulate the same kind of critique against Rawls's conception of primary goods: "most importantly for our purpose, Rawls's primary goods arbitrarily leave out of consideration abnormal needs and handicaps" (p. 89).

${ }^{12}$ This of course does not mean that the hard cases are unimportant for Rawls. But he thinks that health and medical needs of citizens "can be decided at the legislative stage in the light of existing social conditions and reasonable expectations of the frequency of illness and accident" (1982, p. 168).
} 
approach of the holdings of primary goods provides a view of freedom of choice, he has fallen, according to Sen (1982b), into the trap of "commodity fetishism," in which goods are regarded as valuable in themselves, and not for the benefits they bestow upon the person "Rawls takes primary goods as the embodiment of advantage rather than taking advantage to be a relationship between persons and goods" (p. 366). The problem with Rawls's conception of primary goods is that they are only seen as means to ends. Although the focus on the index of primary goods can be seen in some respects as an index of freedom, this index pays no attention to the diversity of human beings in terms of special health and other needs. Primary goods suffer from the "fetishist" handicap of being concerned with goods rather than what these good things do to human beings. In that sense primary goods do not reflect sufficiently each person's freedom of choice to achieve valuable functioning and well-being equally. (See on "commodity fetishism" in general: Sen, 1985 b, p. 28. In relation to Rawls's primary goods, see also Sen, 1982b, p. 366).

Rawls (1988) has responded to the critique formulated by Sen (1982b). He summarizes his interpretation of Sen's objection in the following way:

[T] he idea of primary goods must be mistaken. For they are not what, from within anyone's comprehensive doctrine, can be taken as ultimately important: they are not, in general, anyone's idea of the basic values of human life. Therefore, to focus on primary goods, one may object, is to work for the most part in the wrong space-in the space of institutional features and material things and not in the space of basic moral values. (pp. 258-259)

Rawls's (1988) response to his interpretation of Sen's objection is the following: "In reply, an index of primary goods is not intended as an approximation to what is ultimately important as specified by any particular comprehensive doctrine with its account of moral values" (p. 259). However, this reply of Rawls seems to miss the point Sen was trying to make, as Sen (1989, pp. 27-34) has noted. Evaluation of capability need not be based on one particular comprehensive doctrine: Capability reflects a person's freedom to choose between alternative lives. The point is that disadvantaged persons may get less from primary goods. As Sen remarks: "Rawls is right to think that my objection did relate to primary goods being means only, but that problem is not disposed of by saying that they are not meant as an approximation of any particular comprehensive doctrine" (1989, pp. $30-31 ; 1990$, p. 119). Rawls stresses the function that primary goods play in assuring that the different conceptions of the good people have can, in practice, be realized. Although he is sympathetic to this inter-end variation, Sen is more concerned with inter-individual variation in the relationship between resources and the freedom to pursue ends. It is this diversity, the 
variations between people in their ability to convert resources into actual freedoms, that Sen (1990) tries to capture with his concept of capabilities.

Rawls's theory may be interpreted as formulating a defense for a comprehensive principle of neutrality whose implementation would guarantee that each citizen has an equal opportunity to pursue in their lives any ideal of the good of their own choosing. However, especially with the help of Sen's arguments, we now have seen that Rawls's solution to the question of which resources are up for neutral distribution is inadequate. We shall have to look for another solution to the question of which resources are up for neutral distribution.

\section{Dworkin's Approach: Equality of Resources}

The critique of Rawls's primary goods approach may lead to the idea that, when searching for a solution to the question of which resources are up for neutral distribution, what we really are concerned with are levels of welfare, not of income, wealth, or such in their own right.

Dworkin (1981a) has thoroughly criticized the idea that it is welfare that liberal principles of justice should be concerned with distributing. He considers

two general theories of distributional equality. The first (which I shall call equality of welfare) holds that a distributional scheme treats people as equals when it distributes or transfers resources among them until no further transfer would leave them more equal welfare. (p. 186)

After various arguments Dworkin concludes that equality of welfare is not so coherent or attractive an ideal as it is often taken to be. Equality of welfare, taken to be a theory about treating people as equals, turns out to be weaker than one may have initially thought. One of the main objections Dworkin makes against welfare equalitarianism is that people have incommensurable conceptions of welfare, conceptions so different that it is meaningless to compare the welfare of different people. This means that no theory of equality of welfare is consistent with the demands of liberalism for neutrality among conceptions of the good. Equality of welfare is, therefore, according to Dworkin not a desirable political goal.

Instead Dworkin (1981a) offers equality of resources as the adequate resourcist theory of distributive justice. This second theory "holds that it treats people as equals when it distributes or transfers so that no further transfer would leave their shares of the total resources more equal" (p. 186). With equality-of-welfare ethics, resources are redistributed to equalize welfare. In the case of equality-of-resource ethics one redistributes resources equally, not, as Roemer (1985) has pointed out 
without any regard to welfare, but because we are motivated to improve, at least somewhat, the welfare of those who began with few resources. We wish to start people from a position of equal resource opportunities, not for the sake of some abstract symmetry, but because this will improve the welfare of those who otherwise would have been relatively lacking in resources. (p. 173)

For Dworkin resources are defined broadly, as they include not only alienable assets but also nontransferable ones of various kinds (talents, handicaps, and various inborn propensities) which a person cannot be deemed responsible for having.

Much of this argument is concerned with what equality of resources might really mean and Dworkin argues that the idea involves both the operation of an economic market and the assumption of the existence of some insurance markets covering differences of abilities and productive power to make the equality of resources a persuasive moral criterion.

In several powerful critiques of Dworkin's project, a number of theorists have shown it to be a failure. Roemer (1985, p. 172), for instance, has argued that equality of resources worsens the welfare of the resourcepoor. If equalizing resources is designed to improve the welfare of those who are resource-poor initially, then of course it cannot be a plausible alternative to equality of welfare. Roemer $(1985$, p. 156) shows that there is no acceptable conception of resource egalitarianism that does not reduce to recommending equality of welfare. And if, Roemer argues, equality of welfare is impossible under the constraint of liberal neutrality (which was Dworkin's objection against welfare egalitarianism), then so is any plausible equality of resources (see Roemer, 1985, pp. 177-178, 1986; Varian, 1985; Scanlon, 1986; Arneson, 1989).

Alexander and Schwarzschild (1987) for their part, argue that Dworkin "is caught between an intuitively unattractive version of equality of resources that excludes consideration of special needs and handicaps, and a version that is more appealing but that collapses into equality of welfare" (p. 103). Like Roemer, they conclude that Dworkin's replacement of equality-of-welfare with resources is a failure. At the same time they agree with Dworkin's critique of equality-of-welfare theories: none of those is consistent with the demands of liberalism for neutrality among conceptions of the good.

Finally, Sen rejects Dworkin's focus on equality of resources. This is mainly due to the fact that Dworkin argues against bringing in handicaps into the idea of equality of resources as such (Sen, 1984, p. 321). In fact, Sen (1984) repeats the critique against Dworkin that he formulated against Rawls's idea of primary goods. Dworkin underestimates the general nature of the problem of the interpersonal differences:

depending on our body size, metabolism, temperament, social conditions, etc., the transiation of resources into the ability to do things does vary substantially from 
person to person and from community to community, and to ignore that is to miss out on an important general dimension of moral concern. (p. 323)

We have to reach, I think, the same conclusion as in Rawls's case. Dworkin's solution to the problem of making the comprehensive principle of neutrality a working principle must be considered a failure.

\section{Liberalism, Neutrality, Primary Goods, and Equality of Resources}

In the foregoing we have seen that, with regard to which resources are up for neutral distribution, the approaches of both Rawls, and Dworkin are inadequate. Their solutions are inconsistent with liberalism's demand for neutrality among different conceptions of the good citizens have.

Alexander and Schwarzschild (1987) come to the same conclusion. They started their analysis with the remark "that only Rawls and Dworkin have attempted to work out" such a neutral theory (p. 88 , italics added). It can come as no surprise then that they conclude at the end of their article that the failure of both theories

leaves liberalism with only one remaining option. It must reject neutrality as a fundamental principle. Liberalism must be defended, not as a theory morally prior to any theory of the good, but as a component of such a theory, or as one value or set of values among a large set (p. 109).

Their conclusion should however be rejected. The comprehensive principle of neutrality, with its lexical priority of government activity to ensure for all persons a reasonable opportunity to pursue their own conceptions of the good, should still be defended. One good reason for this defense is that, contrary to what Alexander and Schwarzschild think, not only Rawls and Dworkin have attempted to work out a neutral theory of resource holdings but that there is at least one other theory that has also made the attempt. It is argued in the following that, unlike Rawls's and Dworkin's theories, it does not fail. This is the approach developed by Sen.

\section{Sen's Approach: Basic Capabilities}

Sen criticizes Rawls's approach of primary goods because Rawls does not cope in any effective way with the problem of the fundamental diversity of human beings (Sen, 1982b, p. 357).

As stated earlier, the availability of an adequate range of options derives its value from the contribution it makes to the equal freedom of each person to lead a good life of his own choice. The freedom to choose between alternative conceptions of the good and political neutrality go hand 
in hand. In this perspective the recognition of the fundamental diversity of human beings has very deep consequences (Sen, 1982b, p. 321). Sen (1988) stresses this point in the following way:

A theory of freedom has to come to grips with the enormous heterogeneity of human beings in terms of personal, social and natural characteristics. The crucial issue in identifying the nature of 'freedom of choice' relates to the question: Choice of what? (p. 278)

The Rawisian (and for that matter Dworkinian) notions are, according to Sen (1984), "moves in the right direction, but they seem to me to be generally deficient as moral criteria, and in particular take inadequate note of the ideas behind positive freedom" (p. 323). What is especially missing in both approaches is what Sen calls, some notion of "basic capabilities": a person's ability to do certain things. This concern with positive freedoms leads directly to valuing people's capabilities and those things that would serve to enhance those capabilities. The notion of capabilities relates, Sen remarks, closely to the functioning of a person. ${ }^{13} \mathrm{Or}$, as he has formulated it more recently:

If the positive conception of freedom is to reflect our ability to achieve valuable functioning and well-being, then there is clearly a case for viewing this freedom in terms of alternative bundles of functioning that a person may be able to achieve. (Sen, 1988, p. 278)

One instance is the ability to move about effectively; but one can consider other abilities, for instance, "the ability to meet one's nutritional requirements, the wherewithal to be clothed and sheltered, the power to participate in the social life of the community" (Sen, 1982b, p. 367). To argue that resources should be devoted to remove or substantially reduce the handicap of the cripple despite there being no primary good deprivation, the case must rest on the interpretation of needs in the form of basic capabilities. That is the solution to the lack of freedom to choose various functionings. The freedom to choose between alternative functioning bundles reflects a person's advantage: his or her capability "to function" (Sen, 1988, p. 279). This interpretation of needs and interests is often implicit in the demand for equality. This is what Sen defines as "basic capability equality" (Sen, 1982b, p. 368).

This focus by Sen on basic capabilities (1982b) can be seen "as a natural extension of Rawls's concern with primary goods, shifting attention from goods to what goods do to human beings" (p. 368). In the same way there is a congruence between the requirement of equality of capabilities and that of equality of resources, but here the problem is, as Sen notes,

${ }^{13}$ See Sen $\left(1982^{b}\right.$, pp. 367-368); (1984, p. 324). See also for the link between the capabilities approach and the ideal of positive freedom: Sen $\left(1985^{a}\right.$, p. 201). 
that Dworkin argues against bringing handicaps into the idea of equality of resources as such (Sen, 1984, p. 321).

To be in favor of the principle that there should be equal freedom to choose between alternative conceptions of the good life involves acknowledging that capability to function comes closest to this conception of freedom. If this freedom is valued then capability itself should serve as an object of value and moral importance, because capabilities specify what a person can or cannot do, or can or cannot be. ${ }^{14}$ In the context of our discussion of neutral theories of resource holdings we conclude that Sen's idea of basic capabilities is an approach that solves liberalism's demand for neutrality among the different conceptions of the good citizens have. (It should be pointed out that in his discussion of the shortcomings of primary goods and equality of resources, and in formulating his own conception of basic capabilities, Sen nowhere himself places this discussion in the context of the debate of liberalism, conceived as political neutrality. However, as should be clear from the discussion in my article, Sen's theory of basic capabilities can be accommodated within this debate).

\section{CONCLUDING REMARKS: A DEFENSE OF NEUTRALITY}

In this article liberalism has been defined as a theory in which one of the main values of the liberal political order is the neutrality of the state. Given the plurality of conceptions of the good, the government should be neutral between these conceptions. In fact, the comprehensive principle of neutrality formulates one of the main goals of governmental authority, with lexical priority over other tasks: ensuring for all persons a reasonable opportunity to pursue the good of their own choosing.

The justification of political neutrality has been based on the desire to show everyone equal concern and respect. Equal freedom of choice can be guaranteed by this principle of neutrality. In that sense freedom and neutrality are closely connected.

Assuming moral pluralism, Rawls looks for a basis of agreement other than that of a general and comprehensive doctrine. He stresses the important public role a neutrally recognized political conception of justice has to play. His suggestion is that his own conception, that of justice as fairness,

\footnotetext{
${ }^{14}$ See Sen (1984), pp. 315-316). See also Sen (1989) where he, once again, formulates his main ideas on basic capabilities. See also Arnesho (1987) who remarks in regard to the three resourcist approaches, those of Rawls, Dworkin, and Sen, that "Sen's emphasis on capabilities is perhaps the most plausible because people vary greatly in the rates at which they transform resources into capabilities and surely we care about resource shares because we care what people can do with their resource shares" (1987, p. 531).
} 
can play such a role. This conception is intended to solve the question of how to regulate the terms of social cooperation between citizens in such a way that each will have the equal ability to pursue his own conception of the good.

The communitarian, nonliberal, view is that the political order must subordinate justice to a higher, more substantive, ideal than the conceptions of the good citizens have. It may be contrasted with liberalism as neutrality. Sandel, a typical example of this line of thought, criticizes Rawls's theory for formulating an abstract conception of justice that does not presuppose any conception of the good life, and that sees the self only in disencumbered terms. An ideal of what we should be as persons can only be connected with a conception of the political order when it is expressed in the primary ideals of that order.

However Rawls's position can be defended against such an attack because communitarian ideas like those of Sandel make freedom, the freedom of choice of one's own conception of the good, impossible. A conception of the good can be imposed upon us by the community. The equal opportunity to pursue in one's life an ideal of the good of one's own choosing implies the rejection of the idea that the state should be seen as a community. The comprehensive principle of neutrality may be strongly defended against communitarian attacks.

When we came to the question how to create conditions of equal opportunity for people to choose any conception of the good with a reasonable opportunity of realizing that conception, we examined Rawls's conception of primary goods. We reached the conclusion that his answer created some problems. This should not lead us, however, to abandon the search for conditions of equal opportunity for people to choose a conception of the good, or even to lead us to abandon, more generally, political liberalism understood as neutrality. ${ }^{15}$ Sen's capability approach is a more satisfactory solution to the question of what conditions create neutrality.

In this regard it should be noted that, for instance, Ameson (1987) has suggested that Sen's capability approach has, in fact, a perfectionist component. His problem with Sen's approach is that

opportunities themselves must be measured and a welfarist will insist that the proper measure of an individual's opportunities is that individual's valuation of

\footnotetext{
${ }^{15}$ See also Jones (1989), who takes a stand against those who think that "liberalism both is and should be founded upon a theory of the good. There are also many others (myself included) who still hope that something approximating to the neutralist position can be sustained for, if liberals have ultimately to accept that they, no less than their opponents, seek merely to impose a favored form of life upon others, liberalism will have lost much of its distinctiveness and appeal" (p. 34). See also Barry (1990b) for an argument in which doubt is raised about the usefulness of the neutralist position in arguing for liberal institutions.
} 
them. Opportunities should be measured as opportunities for welfare or preference satisfaction. Insofar as Sen's capabilities approach holds that opportunities can be measured independently (or partly independently) of welfare, there is a perfectionist component to his approach. (p. 532, note 24)

However, this line of reasoning seems to me to be incorrect. The fact that Sen's "capabilities" can be measured in an objective way, does not imply perfectionism. It only means there is an objective standard for measuring instrumental resources that are means to ends. (Following Arneson's reasoning, Rawls's conception of primary goods would also lead us to the conclusion that it was a perfectionist approach.) Sen himself distinguishes between "self-evaluation" and "standard-evaluation." What is relevant here is that the capability approach has to do with self-evaluation: It tells us what the person would judge to be his standard of living in comparison with other positions (Sen, 1987, p. 30).

Our general conclusion is, then, that if one favors freedom of choice, one should defend the comprehensive principle of neutrality with its lexical priority for government to create the equal opportunity to advance any permissible conception of the good. That would create a truly liberal political order.

\section{ACKNOWLEDGMENTS}

For helpful comments on earlier drafts of this article I am most grateful to Dick Ashcraft, G. A. Cohen, John Rawls, Amartya Sen, and Albert Weale.

\section{APPENDIX A}

For a fundamental misunderstanding of the liberal notion of neutrality of the state, see Mouffe (1988), where it is stated:

Unfortunately too many liberals want to identify political liberalism with the neutral state and do not understand that it is a mistaken and self-defecting strategy. Some like Charles Larmore even argue that the task of liberal theory is to provide a neutral justification of the neutrality of the state. (p. 112)

This neutrality is interpreted by Mouffe to imply that "neutral experts" take over political decisions and that, in general those decisions are defined as "administrative and technical" ones. To be sure this is not what Larmore understands to be the meaning of the liberal notion of neutrality. The misunderstanding becomes even clearer when Mouffe continues with the remark: "To be sure Rawls does not endorse those claims to neutrality and 
... his theory of justice is getting increasingly loaded with values" (p. 112). Indeed, Rawls does not endorse "those claims to neutrality," but neither does Larmore.

\section{APPENDIX B}

One may wonder if one can fairly attack Sandel's interpretation of Rawls's theory as formulated in his $A$ Theory of Justice (1971), with thoughts Rawls has published only after Sandel published his book in 1982. The answer is that, first of all, $A$ Theory of Justice already harbors both the Kantian and the modus vivendi view. Second, Sandel acknowledges in his book Rawls's "Kantian Constructivism in Moral Theory" published 2 years before Sandel published his book (Rawls, 1980). This, according to Wallach, tends "to place Sandel's book qua Rawisian critique in the category of interesting misreadings of $A$ Theory of Justice" (1987, pp. 608-609, note 7). See also Rorty on Sandel's (mis)interpretation of Rawls's view where Rorty rebuts some of the objections to Rawls Sandel formulates (Rorty, 1988, pp. 264-268). Finally one could quote Gutmann (1985):

Someone might reasonably argue that not until "The Dewey Lectures" does Rawls consistently and clearly defend the position on justification that I attribute to him (the modus vivendi view, P.B.L.). Had Sandel directed his criticism only against $A$ Theory of Justice, his interpretation would have been more credible. But he still could not have sustained his central claim that Rawls's principles and liberalism more generally must rest on implausible metaethical grounds. (p. 312 , note 18)

\section{REFERENCES}

Ackerman, B. A. (1980). Social Justice in the Liberal State, Yale University Press, New Haven, CT.

Ackerman, B. A. (1983). What is neutral about neutrality? Ethics 93: 372-390.

Alexander, L., and Schwarzschild, M. (1987). Liberalism, neutrality, and equality of welfare vs. equality of resources. Philos. Public Affairs 16: 85-110.

Arneson, R. J. (1987). Meaningful work and market socialism. Ethics 97: \$17-545.

Arneson, R. J. (1989). Equality and equal opportunity of welfare. Philos. Stud. 56: 77-93.

Barry, B. (1990a). Political Argument; A Reissue with a New Introduction, University of California Press, Berkeley, Los Angeles.

Barry, B. (1990b). How not to defend liberal institutions. Br. J. Polit. Sci. 20: 1-14.

De Marneffe, P. (1989). Liberalism and Education. Unpublished Doctoral thesis, Department of Philosophy, Harvard University.

De Marneffe, P. (1990). Liberalism, liberty, and neutrality. Philos. Public Affairs 19: 253-274.

Dworkin, R. (1977). Taking Rights Seriously, Gerald Duckworth, London, UK.

Dworkin, R. (1978). Liberalism. In Hampshire, S. (ed.) Public and Private Morality, Cambridge University Press, Cambridge, UK, pp. 113-143.

Dworkin, R. (1981a). What is equality? Part 1: Equality of welfare. Philos. Public Affairs 10: 185-246. 
Dworkin, R. (1981b). What is equality? Part 2: Equality of resources. Philos. Public Affairs 10: $283-345$.

Dworkin, R. (1983). Neutrality, equality, and liberalism. In Maclean D., and Mills, C. (eds.), Liberalism Reconsidered, Rowman and Allanheld, Totowa, NJ., pp. 1-11.

Fishkin, J. S. (1975). Justice and rationality: Some objections to the central argument in Rawls's theory. Am. Polit. Sci. Rev. 69: 615-629.

Galston, W. (1982). Defending liberalism. Am. Polit. Sci. Rev. 76: 621-629.

Gutmann, A. (1985). Communitarian critics of liberalism. Philos. Public Affairs 14: 308-322.

Jones, P. (1989). The ideal of the neutral state. In Goodin, R. E. and Reeve, A. (eds.), Liberal Neutrality, Routledge, London, pp. 9-38.

Kymlicka, W. (1988), Liberalism and communitarianism, Can. J. Philos. 18: 181-204.

Larmore, C. E. (1987). Patterns of Moral Complexity, Cambridge University Press, Cambridge, UK.

Mouffe, C. (1988). Rawls: Political philosophy without politics. Philosophy 13: 105-123.

Nagel, T. (1975). Rawls on justice. In Daniels, N. (ed.), Reading Rawls, Basil Blackwell, Oxford, pp. 1-15.

Nagel, T. (1987). Moral conflict and political legitimacy. Philos. Public Affairs 16: 215-240.

Rawls, J. (1971). A Theory of Justice, Harvard University Press, Cambridge, MA.

Rawls, J. (1980). Kantian constructivism in moral theory. J. Philos. 77: 515-572.

Rawls, J. (1982). Social unity and primary goods. In Sen, A., and B. Williams, B. (eds.), Utilitarianism and Beyond, Cambridge University Press, Cambridge, pp. 159-185.

Rawls, J. (1985). Justice as fairness: political not metaphysical. Philos. Public Affairs 14: 223-251.

Rawls, J. (1987). The idea of an overlapping consensus. Oxford J. Legal Stud. 7: 1-25.

Rawls, J. (1988). The priority of right and ideas of the good. Philos. Public Affairs 17: 251-276.

Rawls, J. (1989). The domain of the political and overlapping consensus. NY Univ. Law Rev. 64: $233-255$.

Raz, J. (1986). The Morality of Freedom, Oxford.

Richardson, H. S. (1990). The problem of liberalism and the good. In Douglass, R. B. Mara, G. M., and Richardson, H. S. (eds.), Liberalism and the Good, Routledge, New York, pp. 1-28.

Roemer, J. E. (1985). Equality of talent. Econ. Philos. 1: 151-187.

Roemer, J. E. (1986). Equality of resources implies equality of welfare. Quart. J. Econ. C1: 751-784.

Rorty, R. (1988). The priority of democracy to philosophy. In The Virginia Statute Religious for Freedom; Its Evolution and Consequences in American History, Cambridge University Press, Cambridge, pp. 257-282.

Sandel, M. (1982). Liberalism and the limits of justice, Cambridge University Press, New York. Sandel, M. (1984). Morality and the liberal ideal. The New Republic. May 7: 15-17.

Scanlon, T. (1986). Equality of resources and equality of welfare: A forced marriage? Ethics 97: $111-118$.

Schwartz, A. (1975). Moral neutrality and primary goods. Ethics 83: 294-307.

Sen, A. (1982a). Rights and agency. Philos. Public Affairs 11: 3-39.

Sen, A. (1982b). Equality of what? In Sen, A. (ed.), Choice, Welfare and Measurement, Clarendon Press, Oxford, pp. 353-369.

Sen, A. (1984). Rights and capabilities. In Sen, A. (ed.), Resources, Values and Development, Harvard University Press, Oxford, pp. 307-324.

Sen, A. (1985a). Well-being, agency and freedom. J. Philos. 82: 169-221.

Sen, A. (1985b). Commodities and Capabilities, North-Holland, Amsterdam, The Netherlands.

Sen, A. (1987). The Standard of Living, Cambridge University Press, Cambridge.

Sen, A. (1988). Freedom of choice. Eur. Econ. Rev. 32: 269-294.

Sen, A. (1989). The Territory of Justice, Harvard Institute of Economic Research; Discussion Paper 1425, Harvard University, Cambridge, MA.

Sen, A. (1990). Justice: Means versus freedom. Philos. Public Affairs 19: 111-121.

Taylor, C. (1989). Cross-purposes: The liberal-communitarian debate. In Rosenblum, N. L. (ed.), Liberalism and the Moral Life, Harvard University Press, Cambridge, MA, pp. 159-182. 
Thigpen, R. B., and Downing, L. A. (1987). Liberalism and the communitarian critique. Am. J. Polit. Sci. 31: 637-655.

Varian, H. R. (1985). Dworkin on equality of resources. Econ. Philos. 1: 110-125.

Wallach, J. R. (1987). Liberals, communitarians, and the task of political theory. Polit. Theory 15: $581-611$. 